\title{
ルカによる福音書9章51節〜19章46節にみられる裏返し構造 一対称性仮説に関する検証に向けて一
}

Contrast structure in Luke $9: 51 \sim 19: 46$

- Consideration on Symmetry-hypothesis -

大喜多 紀明 1

1滋賀民俗学会

Noriaki Ohgita $^{1}$

${ }^{1}$ Folklore Society of Shiga

キーワード：裏返し構造, 対称性仮説, ルカによる福音書

Key words : Contrast structure, Symmetry-hypothesis, The gospel by Luke

\begin{abstract}
— 抄録
前稿では，新約聖書に収納された「ルカによる福音書」にみとめられる裏返し構造を紹介した. 本稿では, 前稿を踏まえ,「ルカによる福音書」の約三分の一の範囲を占めるルカによる福音書 9 章 51節〜19章46節をテキストとし，裏返し構造の特徵を照合することにより得られた知見を資料とし て紹介寸る.
\end{abstract}

\section{1. はじめに}

物語の構造分析においては，例えば，ロシア神 話の分析を 31 個の「機能」の観点から行ったウラ ジーミル・プロップの手法(1)や，二項対立の観点 から神話分析を行ったクロード・レヴィニストロ 一スの手法(2)などがよく知られている。そのなか でも，ルーマニアのフォークロリストであるミハ イ・ポップは, ルーマニアの昔話「兵士としての 少女」の物語構造の分析を行ない, そこに裏返し 構造と呼ばれる興味深い構造が見いだされること を紹介した (3).

ポップの知見を受けた大林論文(4)は，日本のい くつかの異郷訪問譚に裏返し構造がみとめられる ことを示したうえで，大林の当該構造が異郷訪問 譚における構造上の「共通の約束」であるという 説(5)を述べた。 大林の推認について, 依田論文(6) は，韓国の異郷訪問譚を題材に検証し，かかる蓋 然性が高いことを示した.ただし，大林の推認は， 異郷訪問譚であれば当該テキストに裏返し構造が 出現すると述べているものの, 裏返し構造が出現 する理由を，当該テキストが異郷訪問譚であるこ とに限定している訳ではない。

一方，大林論文は，異郷訪問譚以外にも裏返し
構造が出現するか否かを検証する必要性を述べた (7). かつ, 従前の大林論文および依田論文では, 異郷訪問譚以外に裏返し構造が出現するか否かの 検証は行われていない.

以上を踏まえ，筆者は，大喜多 (2016) ${ }^{(8)}$, 大

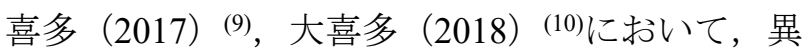
郷訪問譚以外に裹返し構造が出現する事例が存在 するか否かを検証し，アイヌロ承テキストおよび 聖書テキストにおける，異郷訪問譚ではないのだ が裏返し構造がみとめられるいくつかの事例を示 した。なお，かかる裏返し構造が出現する理由に ついては，アイヌロ承テキストや聖書テキストに は一般に交差対句(11)が頻用されることが知られて おり(12)(13)，こうした交差対句の使用を好む心性に 一因寸る可能性を筆者は提示した ${ }^{(14)}$ 。なお，聖書 テキストを題材に対称性仮説の蓋然性を検証した 論文が，大喜多（2017），大喜多（2018）である. ここで,アイヌロ承テキストと聖書テキストは, 先行研究(12)(13)に基づけば，双方とも，交差対句を 好む心性がみとめられてきた。 その一方，アイヌ 口承テキストの著者はアイヌ民族（単一の民族） である。それに対し，聖書テキストの著者は，一 般的にはイスラエル民族であると言えようが，例 
えば，著者の立証が事実上不可能(15) とされる「創 世記」や，イスラエル民族出身者を著者としない (16)「ルカによる福音書」,「使徒行伝」などがある. つまり，聖書に収納された各巻には，著者が明ら かではないものがある．かつ，著者が単一の民族 の出身者であるとも言えない(17)

以上より，聖書テキストの場合，イスラエル民 族の民族性あるいは当該民族に共通する心性がテ キストの構造上の特徵に単純に反映されるものと は言えず，むしろ，聖書に収納された各巻を，当 該著者の属性や当該巻の編集史的な知見などを踏 まえ，個別に検証する必要があると言え，そのう えで，聖書全体の特性を検討する必要があると言 える(18).

かかる聖書の特性を前提に, 筆者の前稿(19)では, 聖書に収納された巻に対する個別の検証を行うこ とを目的に,「ルカによる福音書」をテキストとし， 裏返し構造に基づく構造的知見を資料として提示 した.

以下は，前稿で示した，「ルカによる福音書」に みとめられる裏返し構造の図式である(20).

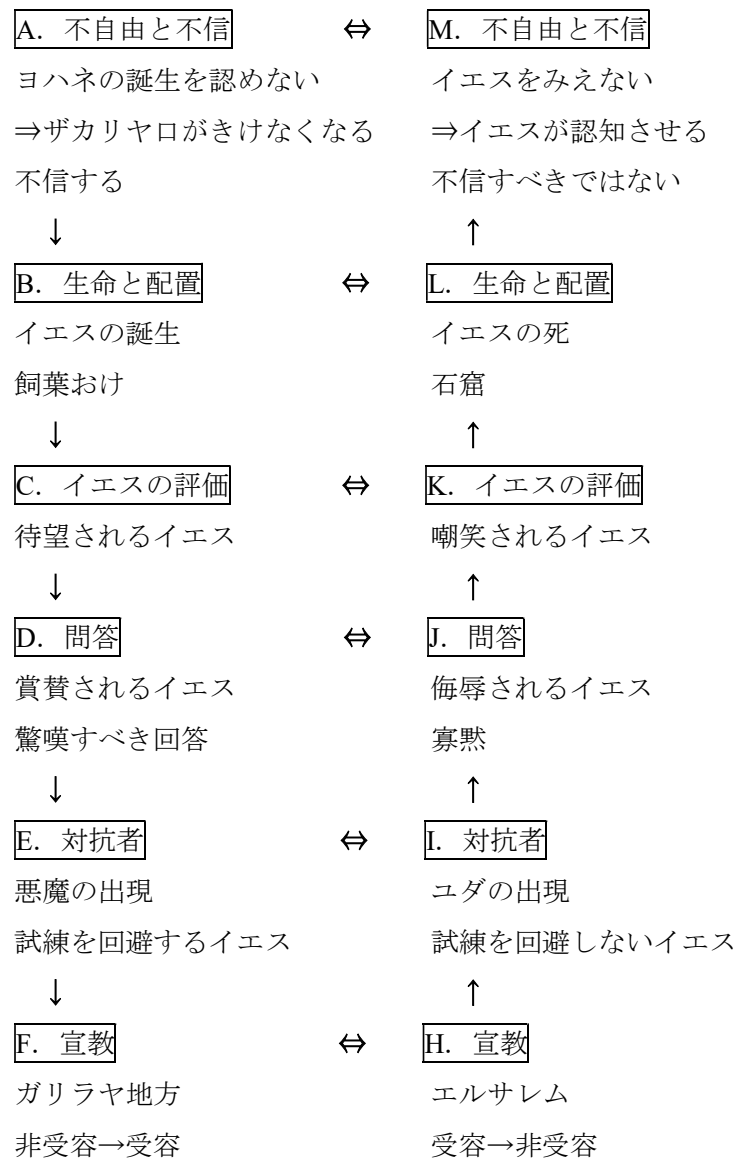

$\downarrow$

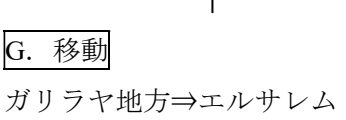

上述の図式では，当該テキストが合計 6 対の対応 を持つ裏返し構造により構成されていることを示 された。

また，前稿では，当該図式を構成する，対応す る要素 $(\mathrm{A}$ と $\mathrm{M}, \mathrm{B}$ と $\mathrm{L}, \mathrm{C}$ と $\mathrm{K}, \mathrm{D}$ と $\mathrm{J}, \mathrm{E}$ と $\mathrm{I}$, $\mathrm{F} と \mathrm{H})$ のそれぞれの関係性について検証された. 一方，要素 $\mathrm{G}$ については，テキスト全体のなかで 占める範囲が相当に広いにもかかわらず，「テキス 卜全体の折り返しに位置している」(21)と述べたの みであり, 詳細な検証は行われていない. そこで, 本稿では，前稿の知見を踏まえつつ，要素 $\mathrm{G}$ に関 する分析を行うこととする.なお, 本稿の目的は, かかる要素 $\mathrm{G}$ に関する分析的知見を資料として提 示するところにある(22).

\section{2. 裏返し構造の定義}

本稿は前稿の知見を前提としている. 前稿では, 以下の A および $\mathrm{B}$ の双方の特徵を満たす構造を 「裏返し構造」と呼んだ.

\section{A：物語の「前半」部分に配置された要素に対し て, 物語の「後半」に相当する要素が，「前半」 の「否定」・対立」もしくは「対照」として の関連性を持って出現する(23) \\ $\mathrm{B}$ : 物語の「後半」に配置された要素は,「前半」 の対応する要素の配列順序とは逆の順番で出 現する(24).}

本稿における裏返し構造の定義も前稿と同様であ る.

\section{3. テキスト}

本稿では，「ルカによる福音書」における前稿の 要素 $\mathrm{G}$ に相当する範囲をテキストとする．要素 $\mathrm{G}$ は，イエス一行がガリラヤ地方からエルサレムへ と「移動」する様子をテーマとしている，当該範 囲は，聖書の章・節立てにおける，ルカによる福 音書 9 章 51 節〜19 章 46 節に相当している. 本稿 ではこれを「テキスト $\mathrm{G} 」 と$ 呼ぶ。

一般的に，ルカによる福音書 9 章 51 節〜 19 章 27 節の範囲は，「イエスのエルサレムへの旅」や 
「ルカの旅行記」などと呼ばれる。さらに，かか るイエスのエルサレムへの旅（ルカの旅行記と同 義）の大部分に相当するルカによる福音書 9 章 51 節〜 18 章 14 節の範囲は「ルカの大挿入」と呼ば れ，著者であるルカが意図的に挿入した箇所であ るとする説がある．このことについて，加藤論文 (25)は次のように述べている.

この大省略と反対に，ルカはマルコになかった 十の章にも及ぶ大きな部分を新たに自分の福音 書の中に持ち込んでいる。 それは九・五一〜一 八・一四の部分である。マルコではイエスは一 ○・一でガリラヤから一挙に, サマリア(26)など, 当然通るべき地域を飛ばしてユダヤに足を踏み 入れる．あえてエルサレムへの旅と呼べる部分 はマルコ一○章のみである。それに対してルカ は，マルコになかった様々な伝承資料を駆使し て，福音書の三分の一以上をイエスがガリラヤ からサマリアを通ってエルサレムに向かう旅の 叙述にあてている.

私にはこの大省略と大挿入はルカの一つの構 想から出るものと思われる。

いずれにせよ，ルカの大挿入あるいはイエスの エルサレムへの旅は，ルカによる福音書の三分の 一程度以上の範囲を占めており，これは，当該福 音書において占める割合としては決して小さいと 言えないものである.また, テキスト $\mathrm{G}$ の範囲は, 大部分において，ルカの大挿入ないしイエスのエ ルサレムへの旅と重なっている。ささらに，ルカの 大挿入について，加藤論文は，イエス一行が「ガ リラヤからサマリアを通ってエルサレムに向かう 旅の叙述」であると述べた。 なお，当該範囲には， 主としてイエスと他者との対話の様子が収納され ている.

また，加藤論文は，ルカの大挿入を著者ルカの 構想により挿入された箇所とみなした。このこと は，ルカの大挿入を大部分とする本稿のテキスト 箇所は，ルカの属性が強く反映された箇所である 可能性を示している.

\section{4. テキストの構造}

本節では，テキスト $\mathrm{G}$ の範囲を $\mathrm{a} \sim \mathrm{v} の$ 合計 22 の断章に区分し，これに基づいた図式を提示する. なお，断章の範囲を示すにあたり，聖書(27)に付さ
れた章・節立てを使用することにする．以下，筆 者が定めた断章の範囲を示す.

$\begin{array}{ll}\text { 断章 } & \text { 章 } \cdot \text { 節立て } \\ \mathrm{a} & 9 \text { 章 } 51 \text { 節 } \sim 9 \text { 章 } 62 \text { 節 } \\ \mathrm{b} & 10 \text { 章 } 1 \text { 節 } \sim 10 \text { 章 } 24 \text { 節 } \\ \mathrm{c} & 10 \text { 章 } 25 \text { 節 } \sim 10 \text { 章 } 42 \text { 節 } \\ \mathrm{d} & 11 \text { 章 } 1 \text { 節 } \sim 11 \text { 章 } 13 \text { 節 } \\ \mathrm{e} & 11 \text { 章 } 14 \text { 節 } \sim 11 \text { 章 } 36 \text { 節 } \\ \mathrm{f} & 11 \text { 章 } 37 \text { 節 } \sim 11 \text { 章 } 54 \text { 節 } \\ \mathrm{g} & 12 \text { 章 } 1 \text { 節 } \sim 12 \text { 章 } 34 \text { 節 } \\ \mathrm{h} & 12 \text { 章 } 25 \text { 節 } \sim 12 \text { 章 } 59 \text { 節 } \\ \mathrm{i} & 13 \text { 章 } 1 \text { 節 } \sim 13 \text { 章 } 9 \text { 節 } \\ \mathrm{j} & 13 \text { 章 } 10 \text { 節 } \sim 13 \text { 章 } 21 \text { 節 } \\ \mathrm{k} & 13 \text { 章 } 22 \text { 節 } \sim 13 \text { 章 } 30 \text { 節 } \\ \mathrm{l} & 13 \text { 章 } 31 \text { 節 } \sim 13 \text { 章 } 35 \text { 節 } \\ \mathrm{m} & 14 \text { 章 } 1 \text { 節 } \sim 14 \text { 章 } 35 \text { 節 } \\ \mathrm{n} & 15 \text { 章 } 1 \text { 節 } \sim 15 \text { 章 } 32 \text { 節 } \\ \mathrm{o} & 16 \text { 章 } 1 \text { 節 } \sim 16 \text { 章 } 8 \text { 節 } \\ \mathrm{p} & 16 \text { 章 } 9 \text { 節 } \sim 16 \text { 章 } 13 \text { 節 } \\ \mathrm{q} & 16 \text { 章 } 14 \text { 節 } \sim 16 \text { 章 } 31 \text { 節 } \\ \mathrm{r} & 17 \text { 章 } 1 \text { 節 } \sim 17 \text { 章 } 37 \text { 節 } \\ \mathrm{s} & 18 \text { 章 } 1 \text { 節 } \sim 18 \text { 章 } 8 \text { 節 } \\ \mathrm{t} & 18 \text { 章 } 9 \text { 節 } \sim 19 \text { 章 } 10 \text { 節 } \\ \mathrm{u} & 19 \text { 章 } 11 \text { 節 } \sim 19 \text { 章 } 38 \text { 節 } \\ \mathrm{v} & 19 \text { 章 } 39 \text { 節 } \sim 19 \text { 章 } 46 \text { 節 }\end{array}$

以上の $\mathrm{a} \sim \mathrm{v}$ の断章に基づき作成した図式を次に 示す.

\begin{tabular}{|c|c|c|}
\hline a. 弟子への叱責 & $\Leftrightarrow$ & v. 弟子への叱責 \\
\hline 出発 & & 到着 \\
\hline 叱責の実行 & & 叱責の拒絶 \\
\hline$\downarrow$ & & $\uparrow$ \\
\hline b. イエスに対する認 & & u. イエスに対する認知 \\
\hline 王も知らない & & 王としての帰還 \\
\hline$\downarrow$ & & $\uparrow$ \\
\hline c. 永遠の生命 & $\Leftrightarrow$ & t. 永遠の生命 \\
\hline 試みる律法学者 & & 教えを乞う役人 \\
\hline エルサレム & & エリコーエルサレム \\
\hline$\downarrow$ & & $\uparrow$ \\
\hline d. 祈䘠方法の伝達 & $\Leftrightarrow$ & s. 祈䘠方法の伝達 \\
\hline 弟子に气われる & & イエスが教える \\
\hline$\downarrow$ & & $\uparrow$ \\
\hline e. 救いの在り方 & $\Leftrightarrow$ & r. 救いの在り方 \\
\hline
\end{tabular}




\begin{tabular}{|c|c|c|}
\hline $\begin{array}{c}\text { 認識可能 } \\
\quad \downarrow\end{array}$ & & $\begin{array}{c}\text { 認識不可能 } \\
\uparrow\end{array}$ \\
\hline f. 預言者の言葉 & $\Leftrightarrow$ & q. 預言者の言葉 \\
\hline 信ぜずに殺害するパ & サイ人 & 死んで地獄に行く金持ち \\
\hline$\downarrow$ & & $\uparrow$ \\
\hline g. 富の扱い & $\Leftrightarrow$ & p. 富の扱い \\
\hline 正当な富 & & 不正な富 \\
\hline$\downarrow$ & & $\uparrow$ \\
\hline h. 主人の評㑑 & $\Leftrightarrow$ & o. 主人の評㑑 \\
\hline 正当な僕への正当な & & 不正な僕への不正な報酬 \\
\hline$\downarrow$ & & $\uparrow$ \\
\hline i. 悔い改为 & $\Leftrightarrow$ & n. 悔い改め \\
\hline 悔い改めないと滅び & & 悔い改めると滅びない \\
\hline$\downarrow$ & & $\uparrow$ \\
\hline j. 安息日の善行 & $\Leftrightarrow$ & m. 安息日の善行 \\
\hline 女の救い & & 息子の救い \\
\hline$\downarrow$ & & $\uparrow$ \\
\hline k. 家の内外の関係 & $\Leftrightarrow$ & 1. 家の内外の関係 \\
\hline 内 : 正当 & $\rightarrow$ & 内 : 不当 \\
\hline 外：不当 & & 外：正当 \\
\hline
\end{tabular}

上述の図式では, $\mathrm{a}$ と $\mathrm{v}, \mathrm{b}$ と $\mathrm{u}, \mathrm{c}$ と $\mathrm{t}, \mathrm{d}$ と $\mathrm{s}$, $\mathrm{e}$ と $\mathrm{r}, \mathrm{f}$ と $\mathrm{q}, \mathrm{g}$ と $\mathrm{p}, \mathrm{h}$ と $\mathrm{o}, \mathrm{i}$ と $\mathrm{n}, \mathrm{j}$ と $\mathrm{m}, \mathrm{k}$ と 1 がそれぞれ対応している. 以下，それぞれの対応 について説明する。

$\mathrm{a}$ と $\mathrm{v}$ についてである。 $\mathrm{a}$ と $\mathrm{v}$ は，旅程の開始時 と終結時における，イエスによる「弟子への吨責」 をテーマとしている、aには，イエス一行が，ガリ ラヤからエルサレムへの移動を開始する場面が描 かれている，その際，まず，サマリヤに先がけて 使者たちが送られるのだが，人々はこれを歓迎し ない，それを知った弟子であるヤコブおよびヨ八 ネは，彼らを焼き払うようにイエスに主張する。 それに対し，イエスは弟子たちを叱ることとなる。 結果，一行はサマリヤへ訪問せず，他の村を経由 していく，一方，vは，イエス一行がエルサレム に到着する場面である。ここでは，イエス一行を 迎えた群衆のなかにいたパリサイ人たちがイエス に対して，弟子たちを叱ることを要請しているの だが，イエスはこれを拒絶する。つまり, a では一 行の旅程の出発が描かれているのに対し，vでは 逆に，かかる旅程の終結が描かれている。また，a ではイエスが弟子たちを叱責するのだが，vでは イエスは弟子たちへの叱責を要請されるものの， それを拒絶する。このように，双方はイエスによ
る「弟子への叱責」をテーマとしているのだが， 叱責の実行と拒絶という対照的な様子が描かれて いる.

$\mathrm{b}$ と $\mathrm{u}$ は，共に，「イエスに対する認知」をテー マとしている.bでは，イエスは 72 人を選定し， 宣教へと送り出した後. 弟子たちに対し，イエス は，あなたたちがイエスと会うことができたこと が幸せなことであり，それは預言者や王たちが願 っても叶わなかったことであると述べた。それに 対し， u では，オリブ山付近でイエス一行を迎え た群衆は，イエスを歓待し，あたかも王のように 迎えられている。つまり，bでは，イエスが預言 者や王からさえも認知されていない存在であるの だが，uでは，イエスは群衆から，王のような立 場の存在として認知されており，双方は対照的で ある。

$\mathrm{c}$ と $\mathrm{t}$ は，「永遠の生命」に関する問答がテーマ である. c では，律法学者が，イエスを試みるため に，「永遠の生命」を得る方法を尋悋た。 それに対 し，イエスは，エルサレムからエリコに下る際に 強盗に襲われた人を救うサマリヤ人の譬えを述べ， これが隣人であり，かつ，当該律法学者が実践す べき規範であると主張した。一方，tでは，役人が イエスに，何をしたら「永遠の生命」が得られる かの教えを乞うている。 それに対しイエスは，財 産を貧しい人に分け与える必要性を説いた。役人 はイエスのこの回答を聞き悲しむ.つまり，c と t は，共に，「永遠の生命」を得る方法をイエスが尋 ねられているのだが，一方は試みるためであり， 他方は真剣に教えを乞うており，双方は対照的で ある。

他にも，cでは，イエスのたとえ話にエルサレム からエリコに下る人物が描写されているのだが, これはあくまでも架空の人物である。それに対し て，tでは，現実のイエスが，これからエルサレム に向かうためにエリコを訪問している。こうした 点も対照的であると言える.

\begin{tabular}{cll} 
断章 & 人物 & 移動方向 \\
\hline $\mathrm{c}$ & 架空の人物 & エルサレム $\rightarrow$ エリコ \\
$\mathrm{t}$ & 現実のイエス & エリコーエルサレム
\end{tabular}

d と s は「祈祷方法の伝達」がテーマである。d においては，イエスは弟子から祈祷の方法を教え てほしいと言われる。 それに対し，イエスは具体 
的な実例を示すことにより，その方法を弟子に教

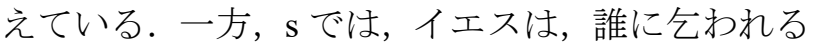
までもなく，人々に対して祈䘠の方法を教えてい る.ただし，ここでは，具体的な実例を示さず， 譬えで教えている.

\begin{tabular}{cll} 
断章 & きっかけ & 方法 \\
\hline $\mathrm{d}$ & 弟子の要請あり & 具体的実例 \\
$\mathrm{s}$ & 人々の要請なし & 譬え
\end{tabular}

かかる， d と s では，共に「祈䘠方法の伝達」をテ 一マとしているものの，相手からの要請の有無や 方法の具体的か否かという点については対照的で ある。

e と rは，「救いの在り方」をテーマとしている. ここで，eでは，人々はイエスの行う業を信ぜず， 「天からのしるし」を求めている. かつ，イエス がソロモンやヨナにまさるものであり，人々に対 し，イエスに注目することを促している。つまり， 人々は人々なりの「救いの在り方」を求めている のだが，イエスはそれを否定し，その代わりとし て現実のイエスを注目し受け入れることにより救

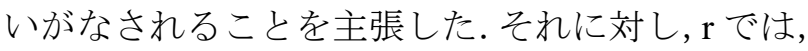
イエスは，罪を赦す立場における心得を弟子たち に述べている，かつ，パリサイ人による「神の国 はいつ来るのか」という問いかけに，イエスは，

「神の国は，見られるかたちで来るものではない」 と告げ, さらに, 弟子たちにも「人の子の日を一 日でも見たいと願っても見ることができない」と 告げた。また，弟子たちからさらに具体的に尋ね られた際, イエスは,「死体のある所には、はげた かが集まるものである」という比喻を述べるにと どまった。つまり，イエスは，「神の国」や「人の 子の日」が通常では目視や認識が不可能であるこ とを述べ，かつ，イエスは比喻を述べるにとどま ったのである.

\begin{tabular}{cll} 
断章 & 救いの在り方 & 認識 \\
\hline $\mathrm{e}$ & 現実のイエス & 可能 \\
$\mathrm{r}$ & 目視できない神の国 & 不可能
\end{tabular}

以上のように, e と $\mathrm{r}$ は，共に救いの在り方をイエ スが述べているのだが，一方は認識できるもので あるのに対し，他方は具体的ではなく比喻による ものであり，かつ，通常では認識できないもので
あり，双方は対照的である。

続いて fと q は「預言者の言葉」をテーマとし

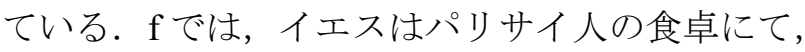
パリサイ人や律法学者が災いであること, 今まで の預言者が殺害されてきたことに対する責任が問 われることを述べている，それに対し，qでは， 欲深いパリサイ人たちがイエスをあざ笑った際, イエスが彼らに，譬え話のなかで，金持ちが死ん で, 火炎で苦しんでいる理由が，彼がモーセと預 言者の言葉に耳を傾けないためであったことを述 ベている．なお，ここでの金持ちはパリサイ人を 比喻したものである.

\begin{tabular}{cl} 
断章 & 死んだ人物 \\
\hline $\mathrm{f}$ & パリサイ人に殺された預言者 \\
$\mathrm{q}$ & 預言者を信じないで地獄で苦しむ
\end{tabular}

つまり,fではパリサイ人は預言者を殺害している のだが，qでは，死んだ立場にあるのが，預言者 の言葉に従わなかったパリサイ人であり，彼は地 獄で苦しみを受けている，かかる双方は対照的で ある。

$\mathrm{g}$ と $\mathrm{p}$ のテーマは「富の扱い」である. $\mathrm{g}$ には, 自分のために富を蓄えるのではなく，天に富を蓄 えること(28)が必要であるという話が書かれている. つまりこれは，正当な富とはいかなるものかとい う話である。それに対し，pには，不正な富を用 いてでも友をつくるべきこと，不正な富に忠実で あるべきことが書かれている，つまりこれは，不 正な富をいかに扱うかという話である。このよう に， $\mathrm{g}$ と $\mathrm{p}$ には，共に「富の扱い」について書か れているものの，それぞれは正当な富と不正な富 についてであり対照的である.

$\mathrm{h}$ と o は，「主人の評価」をテーマとしている. $\mathrm{h}$ には, 主人は忠実な僕には財産を管理させるが, 不忠実な僕は厳罰が与えられるという譬え話が書 かれている。逆に，oには，不正な手口で財産を 増やした家令を主人が集める話が書かれている。 ここでの $\mathrm{h}$ には，正当な僕に対して主人が正当な 評価（報酬）を与えている。他方, o では, 詐欺 行為ともいえる不正な行為により財産を増やした 不正な僕に対して主人は不正な評価（報酬）を与 えており，双方は対照的である.

$\mathrm{i}$ と $\mathrm{n}$ のテーマは「悔い改め」の履行と不履行で ある、iでは，イエスは譬えを駆使しつつ，悔い改 
めなければ滅びることを告げている，対し， $\mathrm{n}$ で は，イエスは「100匹の羊」,「10枚の銀貨」,「放 蕩息子」の譬えを駆使し，悔い改めれば滅びるこ とがないことを告げている。このように，一方に は悔い改めなかった場合，他方には悔い改めた場 合が書かれており対照的である。

$\mathrm{j}$ と $\mathrm{m}$ のテーマは，「安息日の善行」である。 $\mathrm{j}$ では, 安息日にイエスが 18 年間病気の霊につかれ た女を安息日に治療する。対し，mでは，イエス は水腫を患っている男を安息日に治療する，双方 はイエスが安息日に治療を行っているのだが，治 療された人物が女性であることと男性であること が対照的である。

$\mathrm{k}$ と1のテーマは，「預言者への態度」である. $\mathrm{k}$ では，イエスによる，主人の家に入れない僕の譬 え話が書かれている。ここでの主人の家は，預言 者たちが住む「神の国」を表しており，僕は「神 の国」から投げ出された人々を表していると言え る。一方，1には，まず，パリサイ人たちがイエス を殺害しようとしていることをイエスが告げられ， それを機に，イエスは，今までエルサレムが預言 者たちを殺害してきたこと，そのような状況下， イエスはイスラエルを幾度も集めようとしてきた こと，にもかかわらず，エルサレムはそれに応じ ようとしなかったことを述べ，「おまえたちの家 は見捨てられてしまう」と宣言した.ここでの「家」 はエルサレムを指していると言える。つまり，k では，イエスにとって正当な立場にある預言者が 「家」におり，追い出された人々はイエスにとっ て不当な立場であると言える。逆に，1では，イエ スにとって不当な立場にあるエルサレムが「家」 におり，正当な立場であるイエスがそれを見捨て ていると言え，双方は対照的である.

\begin{tabular}{ccl} 
断章 & 家の内 & 家の外 \\
\hline $\mathrm{k}$ & 預言者〔正当〕 & 人々〔不当〕（見捨てられる） \\
1 & エルサレム〔不当〕イエス〔正当〕（見捨てる）
\end{tabular}

\section{5. 裏返し構造との照合}

本節では，4 節に示した構造を，2節に示した 特徴 $\mathrm{A}$ および特徵 $\mathrm{B}$ と照合することにより，かか る構造が裏返し構造と言えるか否かに関して検討 をする。

テキスト $\mathrm{G}$ は, $\mathrm{a} と \mathrm{v}, \mathrm{b}$ と $\mathrm{u}, \mathrm{c} と \mathrm{t}, \mathrm{d}$ と $\mathrm{s}, \mathrm{e}$ と $\mathrm{r}, \mathrm{f}$ と $\mathrm{q}, \mathrm{g}$ と $\mathrm{p}, \mathrm{h}$ と $\mathrm{o}, \mathrm{i} と \mathrm{n}, \mathrm{j}$ と $\mathrm{m}, \mathrm{k}$ と 1
がそれぞれ対応しており，4節の図式に関する検 討に基づけば，それぞれは対照的な関係である。 この特徴は，特徵 $\mathrm{A}$ と合致している。他方，テキ スト $\mathrm{G}$ の前半の要素は $\mathrm{a} \rightarrow \mathrm{b} \rightarrow \mathrm{c} \rightarrow \mathrm{d} \rightarrow \mathrm{e} \rightarrow \mathrm{f} \rightarrow \mathrm{g} \rightarrow \mathrm{h} \rightarrow \mathrm{i}$ $\rightarrow \mathrm{j} \rightarrow \mathrm{k}$ という順序で配列しており，後半の要素は $\mathrm{l} \rightarrow \mathrm{m} \rightarrow \mathrm{n} \rightarrow \mathrm{o} \rightarrow \mathrm{p} \rightarrow \mathrm{q} \rightarrow \mathrm{r} \rightarrow \mathrm{s} \rightarrow \mathrm{t} \rightarrow \mathrm{u} \rightarrow \mathrm{V}$ という順序で配 列している．後半の要素の配列順は，対応する前 半の要素の配列順とは正反対である。この特徵は, 特徵 B と合致している．以上は，テキスト $\mathrm{G}$ は特 徵 A と特徵 B の双方に合致しているので，4節に 示した構造は裏返し構造であることを示している。 よって，テキスト $\mathrm{G}$ は，合計 11 対の対応に基づく 裏返し構造により構成されている。

\section{6. まとめ}

前稿では，ルカによる福音書が， A と $\mathrm{M} ， \mathrm{~B}$ と $\mathrm{L}, \mathrm{C}$ と $\mathrm{K}, \mathrm{D}$ と $\mathrm{J}, \mathrm{E}$ と $\mathrm{I}, \mathrm{F}$ と $\mathrm{H}$ という合計 6 対 の対応と，折り返し位置に相当する要素 $\mathrm{G}$ からな る裏返し構造により構成されることが示された。

一方, 要素 G は, 確かに「移動」というテーマ に基づき構成されているとは言えるものの，当該 範囲が，ルカによる福音書全体の三分の一程度以 上を占め，これは，当該福音書においては決して 狭い範囲とは言えない。このことから，かかる範 囲においても詳細な分析を施す必要であると考え， 本稿では，要素 $\mathrm{G}$ に関する分析を，裏返し構造を 照合する観点から行った。

本稿の分析によれば, 要素 $\mathrm{G}$ は, $\mathrm{a}$ と $\mathrm{v}, \mathrm{b}$ と $\mathrm{u}$, $\mathrm{c}$ と $\mathrm{t}, \mathrm{d}$ と $\mathrm{s}, \mathrm{e}$ と $\mathrm{r}, \mathrm{f}$ と $\mathrm{q}, \mathrm{g}$ と $\mathrm{p}, \mathrm{h}$ と $\mathrm{o}, \mathrm{i}$ と $\mathrm{n}$, $\mathrm{j}$ と $\mathrm{m}, \mathrm{k}$ と 1 という, 合計 11 対の対応に基づく裏 返し構造により構成されていることが確認できた.

以上の知見に基づき，本稿で得たテキスト $\mathrm{G} の$ 構造を単純に前稿のルカによる福音書の裏返し構 造に組み込めば，以下の構造が示されることとな る.

\begin{tabular}{|c|c|c|}
\hline A. 不自由と不信 & $\Leftrightarrow$ & M. 不自由と不信 \\
\hline \multicolumn{2}{|c|}{ ヨハネの誕生を認めない } & イエスをみえない \\
\hline \multicolumn{2}{|c|}{ 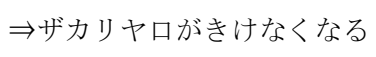 } & ＜wide>イイエスが認知させる \\
\hline \multicolumn{2}{|l|}{ 不信する } & 不信すべきではない \\
\hline \multicolumn{2}{|l|}{$\downarrow$} & $\uparrow$ \\
\hline B. 生命と配置 & $\Leftrightarrow$ & L. 生命と配置 \\
\hline \multicolumn{2}{|l|}{ イエスの誕生 } & イエスの死 \\
\hline \multicolumn{2}{|l|}{ 飼葉おけ } & 石窟 \\
\hline \multicolumn{2}{|l|}{$\downarrow$} & $\uparrow$ \\
\hline
\end{tabular}




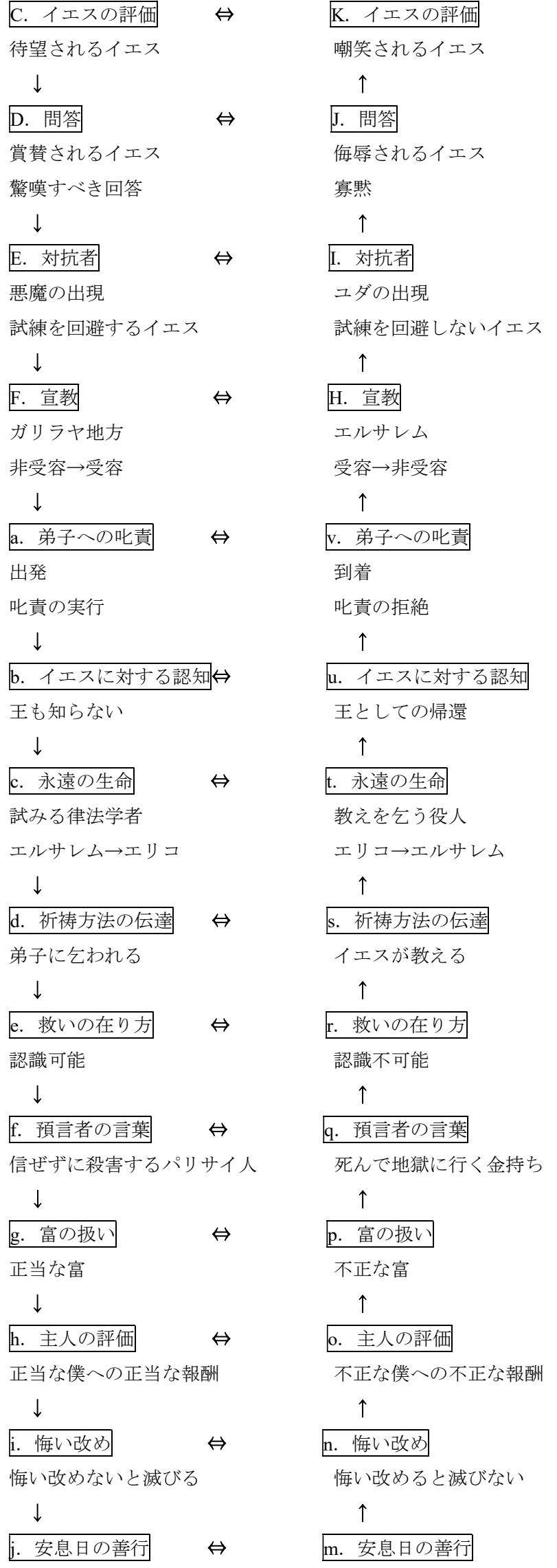

\begin{tabular}{lll} 
女の救い & 息子の救い \\
$\downarrow$ & & $\uparrow$ \\
\hline k. 家の内外の関係 & $\Leftrightarrow$ & 1. 家の内外の関係 \\
内 : 正当 & $\rightarrow$ & 内 : 不当 \\
外 : 不当 & & 外 : 正当
\end{tabular}

つまり，ルカによる福音書は，合計 17 対の対応を 持つ裏返し構造により構成されていると言える. ただし,これは単に, 要素 $\mathrm{G}$ に本稿の構造を組み 込んだことによるものであり，各要素の抽象水準 を検討した結果に基づいている訳ではない。この 点については今後検証するつもりである.

\section{注}

(1)例えば，ウラジーミル・プロップ。北岡誠司， 福田美智代 (訳). 昔話の形態学. 水声社, 1987.

(2)例えば，クロード・レヴィ＝ストロース．田島 節夫（訳）．神話の構造．みすず書房， 1972.

(3)ポップが示した構造の初出は『Folclor Literar』 （1967 年出版）に収納された論文「Metode noi in cercetarea structurii basmelor」である。しかし， 筆者はこれを入手できなかった，本稿では，当 該箇所が掲載された Pop, Mihai. “Coordonate structurale ale folclorului literar". Folclor literar românesc. 1990, p. 77-92.を参照した.

(4)大林太良. 異郷訪問譚の構造. 口承文芸研究. 1979, (2), p.1-9.

(5)本稿では，大林が示した仮説を「大林の推認」 と呼ぶこととする。

(6)依田千百子. 韓国の異郷訪問譚の構造. 口承文 芸研究. 1982, (5), p.47-57.

(7)大林論文の 9 ページを参照した.

(8)大喜多紀明．アイヌロ承テキストに見られる裏 返し構造 : 異郷訪問譚によらない事例. 北海道 言語文化研究. 2016, (14), p.45-72.

(9)大喜多紀明. 聖書「創世記」冒頭の 5 つの物語 の構造 : 異郷訪問譚によらない裏返し構造の事 例. 北海道言語文化研究. 2017, (15), p. 195-216.

(10)大喜多紀明．新約聖書「マタイによる福音書」 の冒頭に配置された $5 つ の$ 物語の構造:「対称性 仮説」の蓋然性. 北海道言語文化研究. 2018, (16), p. $25-48$.

(11)「交差対句」は，「キアスムス」や「交錯配列」 などとも呼ばれるのであるが，本稿では「交差 対句」という呼称を使用する。交差対句とは, 
例えば， $\mathrm{A} \rightarrow \mathrm{B} \rightarrow \mathrm{C} \rightarrow \mathrm{C}^{-} \rightarrow \mathrm{B}^{-} \rightarrow \mathrm{A}^{\prime}$ のように， 要素の対が同心円状に配列する，対称性に富ん だ構造のことである.

(12)例えば，大喜多紀明．アイヌの子守歌（イヨン ルイカ）についての考察：心性が継承される直 接的なプロセス．京都民俗．2013, (30/31), p.

143-158.

(13)例えば, 村井源. マルコ福音書の多層集中構造.

日本カトリック神学会誌. 2009, (20), p. 65-95.

(14)本稿では，「裏返し構造の出現に対し，交差対 句を好む心性が一因する」という仮説を「対称 性仮説」と呼宗。

(15)いのちのことば社. 聖書 新改訳 注釈・索引・ チェーン式引照付．いのちのことば社， 1981. （本稿ではこれを「いのちのことば社（1981） と呼ぶ」）の「旧約聖書」編，「創世記・緒論」 項には次のように書かれている。「原初の歴史 的資料を通して，神がご自身の御旨を啓示され るに当たり，モーセを編集者として用いられた、 と考えることはふさわしいことと思われる。し かし，現在，それを歴史的に立証することは不 可能であろう.」

(16)いのちのことば社（1981）の「新約聖書」編, 96 ページには「ルカによる福音書」の著者ルカ について以下のように書かれている。「新約聖 書の各書の著者のほとんどすべてがユダヤ人で あるのに対し，彼は異邦人であった.」なお，こ こでのユダヤ人とは，事実上，イスラエル民族 に内包される概念である.

(17)いのちのことば社（1981）によれば，著者の信 憑性を検証すべき巻，あるいは，著者が不明な 巻は，「創世記」以外にもある。
(18)本稿ではこれを「聖書の特性」と呼ぶ.

(19)大喜多紀明。「ルカによる福音書」全体におけ る裏返し構造. 人間生活文化研究. $2018,(28), p$. 75-81. なお，本稿ではこれを「前稿」と呼ぶ. (20)「ルカによる福音書」における裏返し構造の図 式は前稿の 77，78 ページに掲載されている.

(21)前稿 79 ページ.

(22)本稿の目的は, テキストの分析的知見を資料と して提供するところにあるので，テキストの構 造と著者の属性との関連に関する考察や，編集 史を踏まえた検証については，本稿では行わな いこととする.なお, 前稿もそうであるのだが, 本稿における分析の手法には恣意が介入する余 地があり，この点が本稿の方法論上の課題であ ることをここに述べておきたい

(23)本稿ではこれを「特徽 A」と呼ぶ.

(24)本稿ではこれを「特徵 B」と呼ぶ.

(25)加藤善治. 民族の枠を越える福音 : 試論・共観 福音書に見るイスラエルから全民族への歩み. 神學研究. 1993, (40), p. 53-78.

(26)「サマリヤ」の表記には「サマリヤ」と「サマ リア」がある．加藤論文では「サマリア」を採 用している.本稿では, 後述の(27)に示すように, 日本聖書協会. 聖書. 日本聖書協会, 1989.に 収納された箇所をテキストとして使用したため, 日本聖書協会 (1989) における表記法である「サ マリヤ」を採用した。

(27)本稿では，日本聖書協会（1989）に掲載された 箇所をテキストとして採用した。

(28)本稿ではこれを「正当な富」と呼ぶことにする.

（受付日：2018 年 9 月 29 日，受理日：2018 年 11 月 9 日） 


\section{大喜多 紀明（おおぎた のりあき）}

現職：一般社団法人地域コミュニティ談話会代表理事.

学籍：自由が丘産能短期大学能率科福祉と心理コース 2 年次.

東京工業大学大学院総合理工学研究科電子化学専攻修士課程修了 (理学修士).

専門は民俗学, 文化人類学.

主な論文：アイヌ女性叙事詩「スズメの酒盛り」についての考察 : 交差対句と心意.アジア民族文化研 究. 2012, (11), p.181-213.

聖書「創世記」冒頭の 5 つの物語の構造 : 異郷訪問譚によらない裏返し構造の事例. 北海道 言語文化研究. 2017, (15), p.195-216. 